\title{
Kopi Arabika-Gayo Menurunkan MDA dan Meningkatkan SOD setelah Latihan Fisik Akut Submaksimal pada Pria Sedenter
}

\author{
Gayo-Arabica Coffee Decreases MDA and Increases SOD \\ after Single Bout Submaximal Physical Exercise in Sedentary Men
}

\author{
MAHMUDIN ARITANOGA ${ }^{1}$, CHOESNAN EFFENDI $^{2}$, LILIK HERAWATI ${ }^{3,4 *}$ \\ ${ }^{1}$ Program Studi Ilmu Kesehatan Olahraga, Fakultas Kedokteran, Universitas Airlangga, Surabaya 60115 \\ ${ }^{2}$ Departemen Fisiologi, Fakultas Kedokteran, Universitas Hang Tuah, Surabaya 60111 \\ ${ }^{3}$ Departemen Ilmu Faal, Fakultas Kedokteran, Universitas Airlangga, Surabaya 60115 \\ ${ }^{4}$ Sport Clinic, Fakultas Kedokteran, Universitas Airlangga dan RSUD Dr. Soetomo, Surabaya 60115
}

Diterima 8 Juli 2019/Disetujui 3 September 2019

\begin{abstract}
It is known that coffee has much phenolic components such as flavonoids and chlorogenic acids (CGAs) content for neutralizing oxidative stress. Gayo-arabica coffee is a typical arabica coffee which widely used by Gayo people in Aceh, Indonesia. The coffee plants also grow in Gayo. However, it has not clearly understood its effect for health. The study aimed is to analyze the Gayo-arabica coffee consumption on the levels of malondialdehyde (MDA) as an indicator of damage cells due to oxidative stress and superoxide dismutase (SOD) as a marker of antioxidant enzyme, after performing a single bout submaximal physical exercise. Male sedentary subjects (21-27 y.o), consisted of 36 men, divided into 3 groups: control (zero of coffee), Gayo1 (15 g coffee in $200 \mathrm{ml}$ water), and Gayo2 (20 g coffee in $200 \mathrm{ml}$ water). Coffee was given once, after rockport test as a single bout submaximal physical exercise. MDA serum and SOD serum were taken after 1 hour of coffee drinking. MDA serum decreased significantly in Gayo1 (8.01 uM) and Gayo2 (10.36 uM), compared to control (26.82 uM). SOD serum increased significantly in Gayo1 (114.81 ng/ $\mathrm{ml}$ ) and Gayo2 $(101.48 \mathrm{ng} / \mathrm{ml})$, compared to control $(24.024 \mathrm{ng} / \mathrm{ml})$. Nevertheless, there was no significantly different between Gayo1 and Gayo2 on MDA and SOD serum (p $\geq 0.05)$. We suggest that the Gayo-arabica coffee after single bout submaximal exercise can diminish stress oxidative in sedentary people.
\end{abstract}

Key words: Arabica coffee, Gayo, MDA, SOD, single bout submaximal exercise

\section{PENDAHULUAN}

Aktivitas fisik berat dan latihan fisik berat diketahui dapat memicu terbentuknya stress oksidatif (Aryanugraha et al. 2012; Irwadi et al. 2018). Selain atlet, aktivitas berat bagi sebagian orang tidak dapat dihindari. Beberapa profesi seperti tentara, buruh tani, dan pekerja kasar kerap dihadapkan dengan aktivitas berat. Efek yang dirasakan dari aktivitas berat ini pun bermacam-macam, seperti kelelahan, nyeri otot, hingga menurunnya produktivitas dan prestasi (Kiyatno 2009). Aktivitas yang berat akan mempengaruhi perubahan pada sistem muskuloskeletal sampai kerusakan otot (Buyukhatipoglu et al. 2010). Aktivitas fisik berat beresiko terhadap kerusakan jaringan serta berpotensi terhadap timbulnya stress oksidatif dan penurunan proteksi antioksidan tubuh (Sholikhah

${ }^{*}$ Penulis korespondensi:

E-mail: lilik_heraw@fk.unair.ac.id et al. 2018). Untuk menangkal stress oksidatif berlebihan, selain antioksidan endogen, diperlukan antioksidan eksogen. Beberapa antioksidan eksogen yang digunakan antara lain vitamin $\mathrm{C}$, vitamin $\mathrm{E}$, dan berbagai tanaman herbal seperti kopi (Martini et al. 2016; Amer et al. 2017; Irwadi et al. 2018).

Salah satu parameter untuk mengetahui stres oksidatif yang meningkat setelah aktivitas atau latihan fisik berat yaitu peningkatan lipid hidroperoksida yang menghasilkan produk akhir berupa malondialdehide (MDA) (Ho et al. 2013). Ketika aktivitas fisik berat berlangsung, kebutuhan oksigen meningkat menjadi 10-15 kali lebih tinggi dibandingkan pada saat istirahat karena terjadi peningkatan metabolisme energi di dalam tubuh (Kurkcu 2010). Meningkatnya kebutuhan oksigen untuk memenuhi energi otot-otot yang berkontraksi, hingga akhirnya dapat memicu produksi elektron yang berlebihan pada rantai transport elektron di mitokondria dan memicu terbentuknya reactive oxygen species (ROS) seperti superoksida, hidrogen 
peroksida, dan senyawa hidrogen yang bersifat radikal (Julien et al. 2006).

Kopi arabika diketahui memiliki komposisi yang berpotensi sebagai antioksidan. Kandungan kopi ini antara lain mineral mangan (Mn), seng ( $\mathrm{Zn})$, dan tembaga $(\mathrm{Cu})$ yang merangsang enzim superoxide dismutase (SOD) bekerja. Minuman kopi juga merupakan sumber utama (49\%) asupan antioksi dan polifenol, komponen polifenol berupa asam klorogenat atau chlorogenic acid (CGA), yakni ester dari asam kafeat dan asam kuinat berperan sebagai antioksidan dan senyawa ini merupakan komponen terbanyak yang terkandung dalam kopi (Liang dan Kitts 2014).

Salah satu jenis kopi arabika adalah kopi arabikagayo. Kopi arabika-gayo adalah kopi khas daerah Gayo, Aceh, Indonesia dan banyak dikonsumsi masyarakat. Tanaman kopi ini banyak tumbuh di Gayo. Namun, efek kopi arabika-gayo terhadap kesehatan belum diketahui. Penelitiam ini bertujuan untuk menganalisis efek kopi arabika-gayo setelah melakukan aktivitas fisik berat yaitu latihan fisik akut dengan intensitas submaksimal terhadap kadar MDA sebagai indikator kerusakan sel akibat stress oksidatif dan SOD sebagai penanda enzim antioksidan.

\section{BAHAN DAN METODE}

Penelitian ini telah mendapat persetujuan dari Komite Etik Penelitian Kesehatan Fakultas Kedokteran Universitas Airlangga (No. 323/EC/ KEKPK/FKUA/2018).

Subjek penelitian adalah laki-laki sehat yang tidak rutin minum kopi dan tidak terlatih berdasarkan International Physical Activity Quesiner (IPAQ) dengan kategori inaktif (Booth 2000), berusia 21-27 tahun. Sebanyak 36 orang yang dibagi secara acak dalam 3 kelompok.

Berat badan dan tinggi badan subjek diukur pada 1-2 hari sebelum pemberian perlakuan. Berdasarkan berat badan dan tinggi badan tersebut, dihitung indeks massa tubuh (IMT) dengan rumus berat badan (dalam $\mathrm{kg}$ ) dibagi dengan tinggi badan kuadrat (dalam meter).

Sebelum dilakukan pemberian perlakuan atau pengambilan data, subjek diminta untuk berpuasa makan selama 8-10 jam (air putih tetap dibolehkan) untuk mendapatkan keadaan yang relatif homogen sebelum penelitian. Selanjutnya, sebelum latihan fisik submaksimal, diberikan minuman manis (gula $1 \mathrm{sdm}$ dalam $200 \mathrm{ml}$ air). Sekitar 30 menit kemudian, subjek melakukan latihan fisik akut submaksimal berupa tes Rockport. Tes Rockport adalah tes fisik submaksimal dengan jalan kaki sejauh 1 mil atau sekitar $1.6 \mathrm{~km}$ dengan durasi secepat mungkin (Rockport Shoes Walking Institute 1986). Lintasan $1.6 \mathrm{~km}$ berupa lintasan 400 meter yang dilalui 4 kali putaran. Saat dilakukan tes Rockport, subjek dilengkapi polar heart rate monitor yang dipasangkan di bagian dada dan berguna untuk mengontrol frekuensi nadi agar dalam intensitas submaksimal yaitu $77-94 \%$ dari heart rate maksimal.

Kopi arabika-gayo yang diberikan adalah berupa kopi murni yang telah disangrai selama 9-11 menit dengan suhu $175^{\circ} \mathrm{C}$ atau disebut dilakukan roasting/ pemanggangan level medium light. Metode roasting tersebut bermanfaat untuk mendapatkan kandungan CGA lebih tinggi (Corrêa et al. 2012). Selanjutnya, kopi digiling sampai halus dan dijadikan seduhan tetes (drip brewing). Drip brewing dilakukan dengan cara meletakkan bubuk kopi sesuai dosis kelompok perlakuan (Gayo1, $15 \mathrm{~g}$; Gayo2, $20 \mathrm{~g}$ ) di atas kertas saring, kemudian kertas saring ditaruh di dalam corong dan dibawahnya diberikan gelas penampung. Selanjutnya air panas $\left(85-95^{\circ} \mathrm{C}\right)$ sebanyak $200 \mathrm{ml}$ dituangkan ke atas kertas saring, dengan bantuan gaya gravitasi, larutan kopi menetes di gelas penampung. Seduhan kopi tersebut diberikan 1 kali setelah latihan fisik akut submaksimal dan frekuensi denyut nadi telah turun sekitar $100 \mathrm{kali} / \mathrm{menit}$.

Pada kelompok kontrol, setelah melakukan latihan fisik submaksimal berupa test Rockport, subjek diberikan air gula (gula 1 sdt dalam $200 \mathrm{ml}$ air). Kelompok Gayo1 dan 2, setelah melakukan test Rockport, subjek diberikan kopi arabika-gayo dengan dosis $15 \mathrm{~g}$ dan $20 \mathrm{~g}$ dalam $200 \mathrm{ml}$ air yang masingmasing ditambah 1 sdt gula untuk mengurangi rasa pahit dari kopi.

Serum darah diambil sebanyak sekitar $5 \mathrm{ml}$ setelah 1 jam pemberian kopi, untuk selanjutnya dilakukan analisis pemeriksaan kadar MDA dan SOD. Pemeriksaan kadar serum MDA (satuan uM) dan kadar serum SOD (satuan $\mathrm{ng} / \mathrm{ml}$ ) dengan metode ELISA.

Data dari 3 kelompok dengan besar sampel 12 per kelompok dianalisis dengan uji Anova, jika data berdistribusi normal, sedangkan bila data berdistribusi tidak normal dianalisis dengan Kruskal Walis. Apabila terdapat berbeda nyata, dilanjutkan dengan uji posthoc LSD atau Mann Whitney untuk melihat perbedaan antar perlakuan. Besar taraf signifikansi ditetapkan 5\%.

\section{HASIL}

Subjek Penelitian. Rerata umur subjek untuk seluruh kelompok penelitian adalah $22 \pm 1.36$ tahun. Rerata umur tidak berbeda nyata antar kelompok $(\mathrm{p} \geq 0.05)$ (Gambar 1). 
Berat badan (BB) untuk semua kelompok mempunyai rerata $63.87 \pm 7.4 \mathrm{~kg}$ dan dengan indeks massa tubuh (IMT) $22 \pm 2.1 \mathrm{~kg} / \mathrm{m}^{2}$. Rerata BB dan IMT tidak berbeda nyata antar kelompok $(\mathrm{p} \geq 0.05)$ (Gambar 2 dan 3).

Kadar MDA. Kadar serum MDA didapatkan perbedaan yang nyata antar kelompok $(\mathrm{p}<0.05)$ akibat pemberian kopi arabika-gayo setelah latihan fisik akut submaksimal. Kadar serum MDA tertinggi adalah kelompok kontrol (26.8 $\pm 8.23 \mathrm{uM})$ dan kadar terendah adalah Gayo1 (8.0 $\pm 6.33 \mathrm{uM})($ Gambar 4). Pada Gayo1 dan 2 tidak didapatkan perbedaan yang nyata $(\mathrm{p} \geq 0.05)$.

Kadar SOD. Pemberian Kopi arabika-gayo memberikan efek yang nyata terhadap kadar serum SOD pada Gayo1 dan 2 dibandingkan kelompok kontrol $(\mathrm{p}<0.05)$. Gayo1 mempunyai kadar serum SOD tertinggi $(101.5 \pm 65.2 \mathrm{ng} / \mathrm{ml})$ dan kelompok kontrol mempunyai kadar serum SOD yang terendah

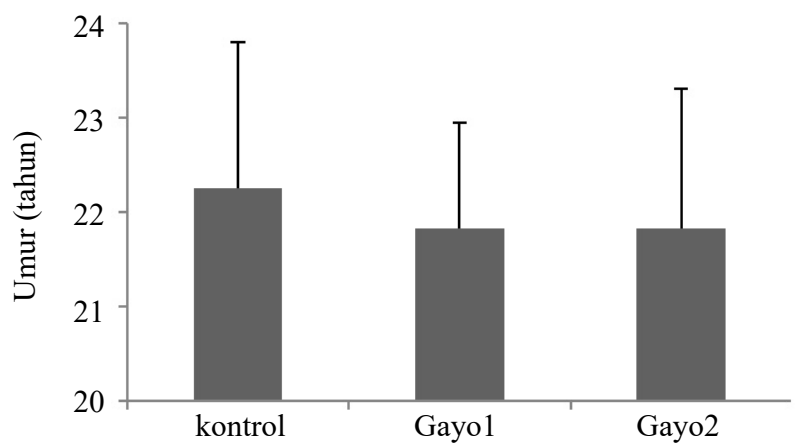

Gambar 1. Rerata umur subjek tiap kelompok ( $\mathrm{p} \geq 0.05$ )

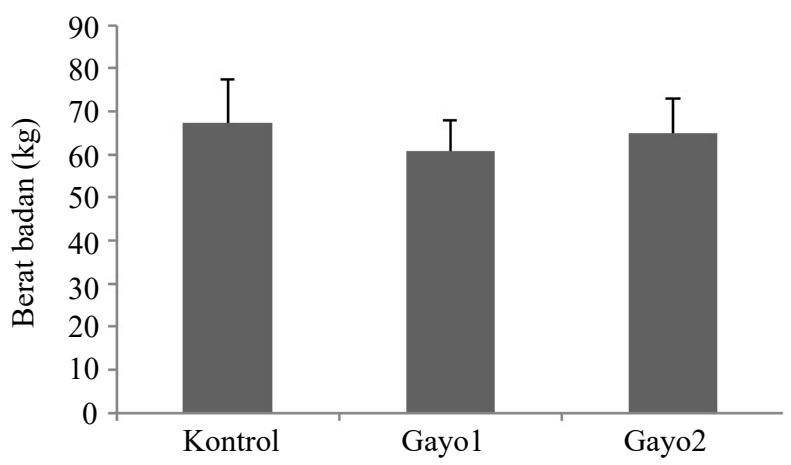

Gambar 2. Rerata berat badan subjek tiap kelompok ( $\mathrm{p} \geq 0.05)$

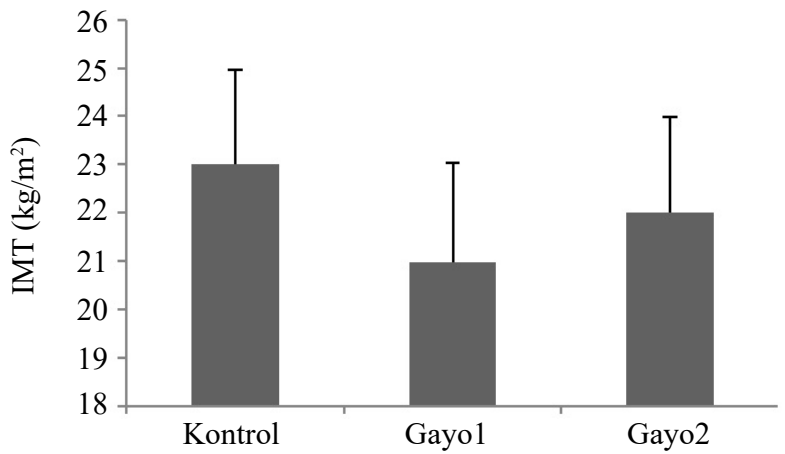

Gambar 3. Rerata IMT subjek tiap kelompok $(\mathrm{p} \geq 0.05)$
(24.0 $\pm 8.1 \mathrm{ng} / \mathrm{ml})$ (Gambar 5), sedangkan Gayo1 dan 2 tidak didapatkan perbedaan yang nyata $(\mathrm{p} \geq 0.05)$.

\section{PEMBAHASAN}

Karakteristik Subjek Penelitian. Subjek penelitian merupakan subjek laki-laki yang tidak terlatih dan bukan peminum kopi yang rutin, sehingga ketika dilakukan latihan fisik akut submaksimal diharapkan stres oksidatif dan efek kopi yang diberikan setelah latihan fisik diharapkan lebih nampak, bukan efek akibat akumulasi kebiasaan minum kopi sebelumnya.

Subjek ini mempunyai rerata umur yang tidak berbeda nyata antar kelompok dan dengan berat badan yang juga tidak berbeda nyata antar kelompok. Menurut Mulato dan Suharyanto (2015) faktor berat badan mempengaruhi waktu paruh metabolisme kafein. Semakin besar berat badan seseorang maka kafein yang dibutuhkan dalam kopi juga semakin meningkat. Oleh karena berat badan pada penelitian ini tidak menunjukkan perbedaan, maka faktor berat badan pada penelitian ini relatif homogen.

Selain itu, dalam penelitian ini dilakukan penghitungan IMT untuk merefleksikan metabolisme energi tubuh. Hal tersebut karena IMT merupakan cara sederhana untuk memprediksi risiko adanya gangguan metabolisme energi. Dari semua sampel penelitian didapatkan rerata IMT

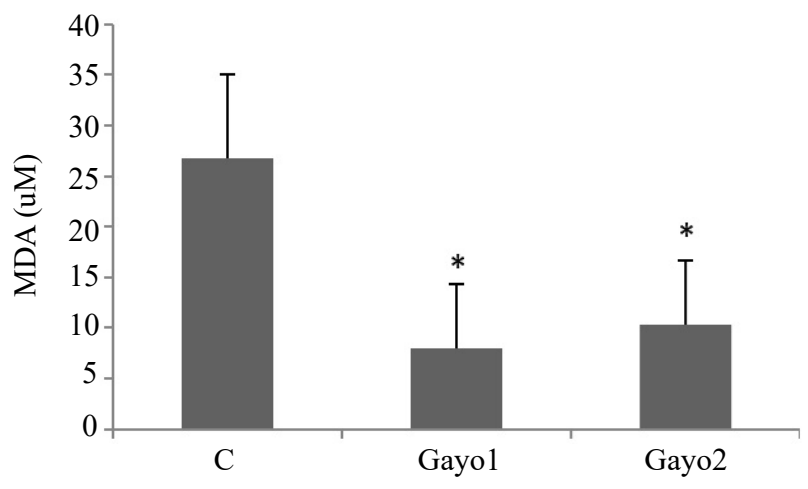

Gambar 4. Rerata kadar MDA (uM) tiap kelompok *berbeda nyata dengan kontrol $(\mathrm{p}<0.05)$

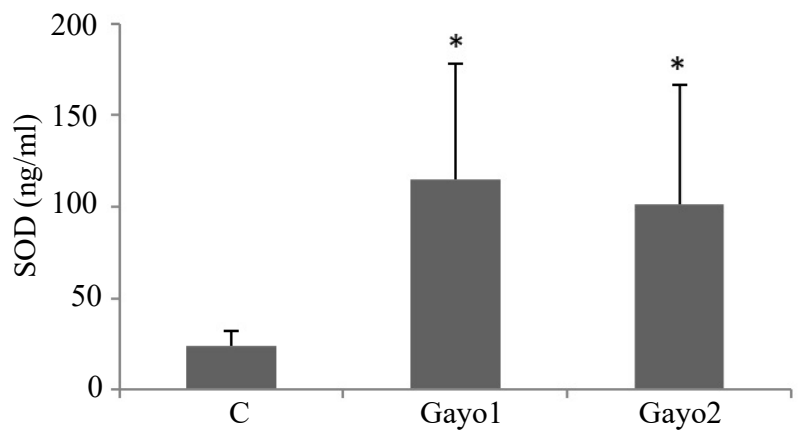

Gambar 5. Rerata kadar serum SOD (ng/mL) tiap kelompok *berbeda nyata dengan kontrol $(\mathrm{p}<0.05)$ 
dengan kategori normal (World Health Organization 2018), namun didapatkan 3 orang subjek dengan IMT pre-obes $\left(25.0 \mathrm{~kg} / \mathrm{m}^{2}\right)$, dengan nilai IMT normal sebesar $18.5-24.9 \mathrm{~kg} / \mathrm{m}^{2}$. Subjek dengan IMT pre-obes tersebut termasuk dalam kelompok kontrol. Namun secara umum, rerata subjek masih dalam kategori IMT normal untuk tiap kelompok dan tidak ada perbedaan antar kelompok, sehingga dapat diasumsikan metabolism energi juga serupa.

Efek Kopi Arabika-Gayo setelah Latihan Fisik Akut Submaksimal terhadap MDA. Pada kelompok kontrol yang diberi stres fisik akut submaksimal (rockport test) tanpa pemberian seduhan kopi arabika-gayo, didapatkan kadar serum MDA paling tinggi bila dibandingkan dengan kedua kelompok lainnya. Hasil ini mengindikasikan bahwa stres fisik akut submaksimal pada subjek yang tidak terlatih menyebabkan terjadinya peningkatan stres oksidatif, sehingga peroksidasi lipid meningkat, yang dapat dilihat dari kadar serum MDA. Hal ini sejalan dengan penelitian sebelumnya, yang dilakukan oleh Zhu dan Zee (2012) dan Aryanugraha et al. (2012) yang melaporkan stressor fisik seperti aktivitas maupun latihan yang berlebihan bisa meningkatkan produksi radikal bebas dalam tubuh yang akan menyebabkan stres oksidatif.

Mekanisme meningkatnya stress oksidatif pada saat melakukan aktivitas fisik berat menyebabkan kebutuhan oksigen meningkat, tetapi asupan oksigen belum mencukupi, sehingga terjadi hipoksia . Pada keadaan ini, xantin dehidrogenase akan diubah menjadi menjadi xantin oksidase (XO). Ketika fase pemulihan, aliran darah akan kembali normal melalui mekanisme reperfusi dan proses ini akan mengaktifkan enzim xantin oksidase, sehingga hipoxantin diubah menjadi xantin maupun asam urat. Reaksi ini menghasilkan efek samping yaitu terbentuknya radikal superoksida $\left(\mathrm{O}_{2}-\right)$ yang bersifat merusak membran sel (Fadlilawati et al. 2019).

Kadar serum MDA pada kelompok Gayol dan 2, lebih rendah daripada kontrol. Berdasarkan fakta ini dapat dikatakan bahwa kandungan aktif yang ada dalam seduhan kopi arabika-gayo berpengaruh pada penurunan kadar serum MDA setelah latihan fisik akut submaksimal pada subjek yang tidak terlatih, setelah 1 jam pemberian seduhan kopi. Hal tersebut dapat disebabkan oleh kandungan kopi yang berupa kafein, flavonoid, dan CGA, menghambat terjadinya kerusakan jaringan yang disebabkan oleh radikal bebas dengan cara menghambat peroksidasi lipid (Ludwig et al. 2014; Amer et al. 2017; Tungmunnithum et al. 2018).

Penjelasan di atas tersebut juga didukung oleh beberapa penelitian sebelumnya, antara lain Lovallo et al. (2005) yang menyatakan bahwa peran kafein dalam mereduksi kadar kortisol. Kortisol adalah hormon yang banyak disekresi pada kondisi stres. Amer et al. (2017) menyatakan bahwa kafein yang terkandung didalam kopi memiliki efek terhadap penurunan kadar MDA yang menunjukkan pengurangan stres oksidatif pada membran sel. Flavonoidjuga berperan dalam melindungi membran sel dari kerusakan yang diakibatkan oleh peningkatan radikal bebas, sehingga bisa mengurangi derajat keparahan pada sel yang diserang. Penelitian yang dilakukan oleh Liang dan Kitts (2014) menyatakan bahwa CGA (chlorogenic acid) dapat meningkatkan kapasitas antioksidan seluler dengan cara mereduksi pembentukan ROS pada sel melalui mekanisme optimal oxygen scavenging dan chain breaking activities secara in vitro. CGA memberikan atom hidrogen sebagai upaya mengurangi radikal bebas dan menghambat reaksi oksidasi.

Kelompok Gayo1 mempunyai kadar serum MDA yang sama dengan Gayo2. Ini mengindikasikan bahwa ada kemungkinan penambahan dosis kopi tidak memberikan manfaat bagi tubuh, namun hal tersebut perlu dilakukan penelitian lebih lanjut. Weinberg dan Bealer (2010) menjelaskan efek kafein digambarkan dengan grafik U terbalik, yang berarti ketika mengkonsumsi kafein dalam jumlah kecil, efek yang ditimbulkan adalah minimal. Sementara kafein dalam jumlah lebih besar akan berefek lebih besar pula, namun konsumsi kafein yang sangat besar, justru menurunkan efek tersebut.

Efek Kopi Arabika-Gayo setelah Latihan Fisik Akut Submaksimal terhadap SOD. Kadar serum SOD merupakan salah satu indikator yang menandakan status antioksidan di dalam tubuh. SOD merupakan antioksidan enzimatik endogen. SOD diperlukan untuk mengimbangi tingginya stress oksidatif dalam tubuh.

Kelompok Gayo1 dan 2 menunjukkan peningkatan kadar serum SOD yang lebih besar daripada kontrol. Rendahnya kadar serum SOD pada kelompok kontrol dapat terjadi terjadi karena adanya ketidakseimbangan antara jumlah antioksidan yang diproduksi oleh tubuh dengan jumlah radikal bebas yang terbentuk akibat latihan fisik submaksimal akut yang dilakukan oleh subjek. Radikal bebas yang terlalu tinggi akan mengganggu sintesis SOD, dan gangguan ini akan menyebabkan penurunan kadar SOD yang diproduksi, sehingga tidak dapat mengimbangi radikal bebas yang terbentuk (Poljsak 2011). Radikal bebas yang terbentuk dapat menimbulkan stress oksidatif yang menimbulkan kerusakan pada membran sel, sehingga sel menjadi rusak, akibatnya, semakin tidak ada lagi aktivitas enzim intraseluler yang berperan dalam aktivitas antioksidan seperti SOD, Glutathion Peroksida (GPx), dan Katalase (CAT) (Li et al. 2015). 
Kopi sebagai bahan antioksidan eksogen dapat meningkatkan enzim antioksidan endogen seperti SOD, katalase (CAT), dan glutation peroxidase (GPx). Kandungan flavonoid dalam kopi bekerja sebagai antioksidan, dengan cara meningkatkan kadar SOD dengan mendonorkan ion hidrogen dan elektron ke anion superoksida, sehingga menjadi lebih stabil untuk melindungi lipo-protein dan DNA dari oksidasi (Dembinska-Kiec et al. 2008). Kandungan CGA dalam kopi bekerja dengan cara scavenging pada radikal bebas, dan kandungan mineral logam menonaktifkan komponen reaktif (Martini et al. 2016). Kafein yang terkandung di dalam kopi berpengaruh menurunkan kadar kortisol yang terbentuk akibat reaksi tubuh terhadap stres yang terjadi, baik stress fisik atau pun psikis, yang secara tidak langsung dapat mengurangi produksi radikal bebas pada vaskular yang terjadi karena turbulensi aliran darah yang dipicu oleh meningkatnya tekanan darah akibat stres (Kala dan Nivsarkar 2016; Abidah et al. 2017).

Pada penelitian ini dosis yang digunakan pada kelompok perlakuan Gayo1 dan 2 yang diberikan setelah latihan fisik akut submaksimal, secara nyata meningkatkan kadar serum SOD subjek. Rerata kadar paling tinggi ada pada kelompok Gayo1 dan 2 , dan yang paling rendah adalah kelompok kontrol. Hasil ini selaras dengan penelitian Abidah et al. (2017) yang menggunakan kopi robusta dengan dosis 20 gram dalam $200 \mathrm{ml}$. Dengan dasar dosis tersebut, dikonversi ke dosis hewan coba mencit yang selanjutnya dipapar stres psikologi. Hasil penelitian tersebut menunjukkan adanya perbedaan yang nyata terhadap peningkatan kadar SOD.

\section{KESIMPULAN}

Pemberian kopi arabika-gayo setelah melakukan latihan fisik akut submaksimal dapat menurunkan stress oksidatif pada individu yang tidak terlatih, melalui penurunan MDA dan peningkatan SOD. Namun, beberapa hal masih perlu dilakukan penelitian lanjutan seperti bagaimana mekanisme dan pemeriksaan kadar hormon stress seperti kortisol dan enzim lain yang mungkin terlibat dalam keseimbangan antioksidan dan radikal bebas.

\section{UCAPAN TERIMA KASIH}

Penelitian ini didukung oleh Program Studi Magister Ilmu Kesehatan Olahraga, Fakultas Kedokteran, Universitas Airlangga.

\section{DAFTAR PUSTAKA}

Abidah RS, Wirjatmadi B, Purwanto B, Adriani M. 2017. Robusta coffee decreased malondialdehyde levels in wistar mice experiencing oxidative stress. Health Notions 1: 330-334.

Amer MG, Mazen NF, Mohamed AM. 2017. Caffeine intake decreases oxidative stress and inflammatory biomarkers in experimental liver diseases induced by thioacetamide: biochemical and histological study. International Journal of Immunopathology and Pharmacology 30:13-24.

Aryanugraha T, Harjanto, HerawatiL. 2012. Effect of combined $500 \mathrm{mg}$ vitamin $\mathrm{C}$ and $200 \mathrm{IU}$ vitamin $\mathrm{E}$ on plasma malondialdehyde level after physical exercise in diving athletes. FMI 48:156-162.

Booth M. 2000. Assessment of physical activity: an international perspective. Research Quarterly for Exercise and Sport 71:114-120.

Buyukhatipoglu H, Kirhan I, Vural M, Taskin A, Sezen Y, Dag OF, Turan MN, Aksoy N. 2010. Oxidative stress increased in healthcare workers working 24-hour on-call shifts. The American Journal of the Medical Sciences 340:462-467.

Corrêa TAF, Monteiro MP, Mendes TMN, Oliveira DM, Rogero MM, Benites CI, Vinagre CG, Mioto BM, Tarasoutchi D, Tuda VL, César LAM, Torres EAF. 2012. Medium light and medium roast paper-filtered coffee increased antioxidant capacity in healthy volunteers: results of a randomized trial. Plant Foods Hum Nutr 67:277-282.

Dembinska-Kiec A, Mykkänen O, Kiec-Wilk B, Mykkänen H. 2008. Antioxidant phytochemicals against type 2 diabetes. British Journal of Nutrition 99:109-117.

Fadlilawati L, Purwanti S, Triliana R, Kedokteran F, Islam U. 2019. Pengaruh frekuensi stres fisik dua hari sekali terhadap kadar malondialdehid (MDA) dan superoksida dismutase (SOD) jaringan jantung tikus betina. Jurnal Bio Komplementer Medicine 6:54-61.

Julien F, Lac G, Edith F. 2006. Oxidative stress relationship with exercise and training. Journal of Sports Medicine 36:327-358.

Ho E, Karimi GK, Liu CC, Bhindi R, Figtree GA. 2013. Biological markers of oxidative stress: applications to cardiovascular research and practice. Redox Biology $1: 483-491$.

Irwadi I, Kinandita H, Mahmud J, Herawati L. 2018. Profile of blood glucose and insulin after vitamin $\mathrm{C}$ and vitamin E supplementation on active teenagers. International Journal of Engineering and Technology 7:136-140.

Kala M, Nivsarkar M. 2016. Role of cortisol and superoxide dismutase in psychological stress induced anovulation. General and Comparative Endocrinology 225:117-124.

Kiyatno. 2009. Antioksidan vitamin dan kerusakan otot pada aktivitas fisik studi eksperimen pada mahasiswa JPOKFKIP UNS Surakarta. Media Medika Indonesiana 43:277-281.

Kurkcu R. 2010. The effects of short-term exercise on the parameters of oxidant and antioxidant system in handball players. African Journal of Pharmacy and Pharmacology 4:448-452.

Li XD, Sun GF, Zhu WB, Wang YH. 2015. Effects of high intensity exhaustive exercise on SOD, MDA, and NO levels in rats with knee osteoarthritis. Genetics and Molecular Research 14:12367-12376.

Liang N, Kitts DD. 2014. Antioxidant property of coffee components: assessment of methods that Define mechanism of action. Molecules 19:19180-19208. 
Lovallo WR, Whitsett TL, Al'absi M, Sung BH, Vincent AS, Wilson MF. 2005. caffeine stimulation of cortisol secretion across the waking hours in. Psychosomatic Medicine 67:734-739.

Ludwig IA, Mena P, Calani L, Cid C, Del Rio D, Lean ME, Crozier A. 2014. Variations in caffeine and chlorogenic acid contents of coffees: What are we drinking? Food and Function 5:1718-1726.

Martini D, Del Bo C, Tassotti M, Riso P, Del Rio D, Brighenti F, Porrini M. 2016. Coffee consumption and oxidative stress: a review of human intervention studies. Molecules $21: 3-20$.

Mulato S, Suharyanto E. 2015. Kopi, Seduhan, dan Kesehatan. Jember: Pusat Penelitian Kopi dan Kakao Indonesia.

Poljsak B. 2011. strategies for reducing or preventing the generation of oxidative stress. Oxidative Medicine and Cellular Longevity 2011:194586. DOI: 10.1155/2011/194586

Rockport Shoes Walking Institute. 1986. Rockport One Mile Walking Test. Malboro: Rockport Walking Institute.
Sholikhah AM, Wirjatmadi B, Adriani M. 2018. Effects of purple sweet potatoes on oxidative stress biomarkers in rats subjected to exhaustive exercise 2:174-177.

Tungmunnithum, D, Thongboonyou A, Pholboon A, Yangsabai A. 2018. Flavonoids and other phenolic compounds from medicinal plants for pharmaceutical and medical aspects: an overview. Medicines 5:2-16.

Weinberg BA, Bealer BK. 2010. The Miracle of Caffeine Manfaat tak terduga Kafein berdasarkan Penelitian Paling Mutakhir. Penerjemah Warastuti; Penyunting, Rani S Ekawati, Nur Aini. Bandung: Qanita.

World Health Organization. 2018. Global Reference List of 100 Core Health Indicators (plus health-related SDGs) 2018. Switzerland: WHO.

Zhu L, Zee PC. 2012. Circadian rhythm sleep disorders. Neurologic Clinics 30:1167-1191. 